\title{
Analysis of Cases of Ergonomic Improvements of Agricultural Work Support Equipments
}

\author{
Dohyung Kee ${ }^{1}$, Young W. Song ${ }^{2}$, Inseok Lee ${ }^{3}$ \\ ${ }^{1}$ Department of Industrial and Management Engineering, Keimyung University, Daegu, 704-701 \\ ${ }^{2}$ Department of Occupational Health, Catholic University of Daegu, Gyeongsan, 712-702 \\ ${ }^{3}$ Department of Safety Engineering, Hankyong National University, Anseong, 456-749
}

\begin{abstract}
Objective: The objective of this study is to present varying cases of ergonomic improvements in equipments for agricultural work. Background: In Korean agricultural sector, many older people and females, who may be more vulnerable to musculoskeletal diseases than young males, are doing high stressful tasks such as manual materials tasks, harvesting, etc. For reducing the work stress of the farmers, the Korean government has been performing support projects to provide the farmers with agricultural implements specified for their crops. In the projects, ergonomics experts have participated and helped modify the equipments. Method: Fifty cases of equipment improvements, which were carried out in 33 farming organizations cultivating 13 different crops, were reviewed and presented by equipments and their parts. Results: In total, 283 cases of improvements for 12 equipments including 4-wheel, 1-wheel, and 3-wheel powered carts, grass cutter, conveyer, pest control machine, and so on, were presented. The improvements were also classified according to the ergonomic principles like compatibility, ease of use, safety and fitting to the anthropometry, etc. Frequencies of improvements by equipment and its part were the highest in carts and controls, respectively. Principles of safety and ease of use were adopted more frequently in improving equipments than others. Conclusion: The tables of examples of improvements of agricultural implements are main results of this study and the systematical summaries are expected to be widely used in the development of more improved agricultural implements. Application: The results could be used as practical guidelines in ergonomically developing and modifying agricultural implements by both the experts and non-experts in ergonomics. The improvements would contribute to reduction of stress in farm work, which result in increasing the level of safety and health of Korean agricultural society.
\end{abstract}

Keywords: Agricultural implements, Ergonomic Improvement, Powered Cart

\section{Introduction}

우리 농촌은 소규모 영농을 기반으로 하고 있다. 적은 수 의 인원이 다양한 유형의 농작업을 과도하게 수행해야 하 는 경우가 많아 작업 조건이 열악한 편이다. 이러한 작업 환경은 다양한 안전 및 보건 문제를 내포하고 있으며, 특히 근골격계질환 위험요인에 대한 농업인의 노출 수준이 높은
것으로 보고되고 있다(Park, 2000; Park and Jeong, 2008; Kee, 2009).

농작업 환경 개선 편이장비 지원 사업은 주로 고령 및 여성 농업인들이 농작업 수행에서 겪는 어려움을 최소화하 고 작업 능률을 향상시키기 위한 소규모 농기계나 보조 장 치를 지원하는 활동으로, 2008년부터 매년 전국적으로 시행 되어 오고 있다. 이 사업은 작목별, 지역별 특성에 맞는 편이 장비를 도입하도록 하고 있으며, 특히 도입 단계에서 인간공

Corresponding Author: Inseok Lee. Department of Safety Engineering, Hankyong National University, Anseong, $456-749$.

Phone: 031-670-5286, E-mail: lis@hknu.ac.kr

Copyright@2011 by Ergonomics Society of Korea(pISSN:1229-1684 eISSN:2093-8462). All right reserved. 
학 및 농기계 전문가들이 편이장비의 선정, 개선, 평가 과정 에 참여하여 보급되는 장비가 실제적으로 농업인들의 작업 부담을 경감시키고 효과적으로 활용될 수 있도록 하고 있다.

이 사업의 실시 초기에는 근골격계질환 유발 유해요인에 해당되는 장시간 반복 동작, 불편한 작업 자세, 과도한 중량 물의 취급 및 운반 등으로 인한 작업 부담을 경감시킬 수 있는 장비의 도입이 권장되었다. 이에 따라 전동 또는 엔진 동력을 이용한 운반차의 보급이 주로 이루어졌으며, 작목반 의 조건에 따라 그 이외의 장비들도 다양하게 보급되었다.

편이장비의 도입 과정에서 인간공학 및 농기계 전문가들 이 참여하여 작목반 상황에 따라 다양하게 장비의 개선을 유도하였으나, 아직 그러한 개선 사례들이 종합적으로 정리 되지 못하였다. 동일한 장비라 하더라도 활용 여건에 따라서 다른 방향으로 개선이 이루어질 수 있으나, 많은 부분에서는 동일한 개선이 적용될 수 있는 것으로 보인다. 그러한 점에 서 개선 사례를 정리하여 자료화하는 것은 농업인의 건강과 안전을 향상시키는데 도움이 될 것이며, 농작업 편이장비를 개발하는 업체가 장비의 품질을 높이는데도 도움이 될 것으 로 기대된다.

본 논문은 농작업 편이장비 지원 사업에 컨설턴트로 참여 한 저자들이 수행한 연구 결과를 종합하고, 장비 유형별로 인간공학적 개선 사례를 요약 정리하여 이를 실용적 정보로 제공하는 것을 목적으로 한다.

\section{Method}

\subsection{Surveyed cases of improvements}

본 논문에서는 14 개 시군(경기도 4 개, 충청남도 7 개, 경 상북도 22 개)의 33 개 작목반에서 실시된 편이장비 지원 사 업의 농작업 편이장비 개선 사례를 조사 대상으로 하였다. 33 개 작목반 중 참외와 포도 작목반이 각각 6 개로 가장 많 았으며, 사과, 오이, 대추 등의 순으로 많았다(Table 1). 조 사 대상 작목반의 작목 재배 환경은 비닐하우스(15개), 과 수원(15)이 주를 이루었다.

33 개 작목반에서 개선이 이루어진 편이장비는 총 50 건 이며, 그 중 21 건(42\%)이 4 륜 동력운반차, 13 건(26\%)이 $1 / 3$ 륜 동력운반차, 그리고 나머지는 제초기, 방제기, 컨베이 어 등이다(Table 2).

\subsection{Analysis of the cases of improvements}

편이장비 개선 사례는 각 장비의 개선 부분별로 개선 내용 을 기술하고, 장비 유형별로 개선 내용을 정리하였다. 장비
Table 1. Number of farming organizations for each crop

\begin{tabular}{c|c}
\hline Crop & $\begin{array}{c}\text { Number of organizations } \\
\text { (Percentage) }\end{array}$ \\
\hline Oriental Melon & $6(18.2)$ \\
\hline Grape & $6(18.2)$ \\
\hline Apple & $5(15.2)$ \\
\hline Cucumber & $4(12.1)$ \\
\hline Jujube & $3(9.1)$ \\
\hline Peach & $2(6.1)$ \\
\hline Miscellaneous crops ${ }^{*}$ & $7(21.0)$ \\
\hline Total & $33(100.0)$ \\
\hline
\end{tabular}

They include strawberry, pear, water melon, onion, chives, tomatoes, and stock raising.

Table 2. Number of agricultural implements

\begin{tabular}{|c|c|c|}
\hline \multicolumn{2}{|c|}{ Agricultural implements } & $\begin{array}{c}\text { Number } \\
\text { (percentage) }\end{array}$ \\
\hline \multirow{3}{*}{$\begin{array}{l}\text { 4-wheel powered cart } \\
\text { (4륜 운반차) }\end{array}$} & 운반차(전동, 4륜) & $10(20.0)$ \\
\hline & 운반차(엔진, 4륜) & $9(18.0)$ \\
\hline & $\begin{array}{c}\text { 운반차 } \\
\text { (승용, 엔진, 4륜) }\end{array}$ & $2(4.0)$ \\
\hline \multirow{2}{*}{$\begin{array}{c}\text { 1- or 3-wheel } \\
\text { powered cart } \\
\text { (1륜 및 3륜 운반차) }\end{array}$} & 운반차(전동, 1륜) & $11(22.0)$ \\
\hline & 운반차(전동, 3륜) & $2(4.0)$ \\
\hline $\begin{array}{l}\text { Powered cart with } \\
\text { caterpillar track } \\
\text { (궤도식 운반차) }\end{array}$ & 운반차(엔진, 궤도) & $1(2.0)$ \\
\hline \multirow{2}{*}{$\begin{array}{l}\text { Grass cutter } \\
\text { (제초기) }\end{array}$} & 제초기(보행) & $2(4.0)$ \\
\hline & 제초기(승용) & $1(2.0)$ \\
\hline \multirow{4}{*}{$\begin{array}{l}\text { Pest control machine } \\
\text { (방제기) }\end{array}$} & 방제기(배부식 동력) & $1(2.0)$ \\
\hline & 방제기(보행식 자동) & $1(2.0)$ \\
\hline & 방제기(자동 호스릴) & $1(2.0)$ \\
\hline & 방제기(자주식 자동) & $1(2.0)$ \\
\hline \multirow{2}{*}{$\begin{array}{l}\text { Conveyor } \\
\text { (컨베이어) }\end{array}$} & 컨베이어(로울러) & $1(2.0)$ \\
\hline & 컨베이어(벨트) & $1(2.0)$ \\
\hline \multicolumn{2}{|c|}{ Miscellaneous equipments ${ }^{*}$} & $5(10.0)$ \\
\hline \multicolumn{2}{|c|}{ Total } & $50(100.0)$ \\
\hline
\end{tabular}

*They include lift, binding machine, sowing machine, work station, and so on.

유형은 운반차(4륜, 궤도), 운반차(1륜, 3 륜), 기타로 분류 하였으며, 기타 장비에는 제초기, 방제기, 컨베이어, 리프트, 비닐자동개폐기, 비닐피복기, 자동결속기, 작업대, 파종기 등 9가지가 포함되었다.

편이장비의 개선에 적용된 인간공학적 개선 원칙은 크 게 양립성(compatibility), 편의성(ease of use), 안전성 
(safety), 인체치수 고려, 기타로 분류하였다. 각 원칙의 정 의와 본 연구에서 적용한 방식은 다음과 같다.

- 편의성은 본 연구에서 개선 사례를 분류함에 있어 포괄적 개념으로 적용되었다. 사용자가 장비를 사용할 때 인지적, 물리적 측면에서 불편함을 느끼거나, 오류를 범할 수 있 거나, 효율적으로 장비를 사용하기 어려울 경우에 편의성 이 미흡하여 개선이 필요한 경우다. 예를 들어, 조종 장치 의 표시 범례가 너무 작아서 운전자가 쉽게 인지하기 어 려운 경우는 편의성이 미흡한 것이라 할 수 있다.

- 양립성이 적용된 개선은 표시 장치나 조종 장치 등에서 공간, 운동, 양식, 개념 측면에서 제품의 설계가 사용자의 기대와 부합하지 않아 개선이 필요한 경우이다. 예를 들어, 정지를 표시하는 범례를 파란색으로 표시하는 것은 개념 양립성에 부합하지 않는 사례이다.

- 안전성은 사용자가 장비를 사용하면서 사고가 발생할 수 있는 위험이 있어 개선이 필요한 경우에 적용된 개선 원 칙이다. 예를 들어, 엔진부가 외부로 노출되어 있어 고온 으로 인해 화상의 위험이 있을 경우는 안전성이 부족하여 개선이 필요한 사례에 해당된다. 또한, 근골격계질환을 예 방할 수 있는 들기 작업을 개선하기 위한 무게, 높이 조절 등도 이에 해당된다.

- 인체치수 고려의 원칙은 장비의 물리적 설계 제원이 사용 자가 사용하기에 너무 작거나 커서 사용자에게 불편을 줄 수 있는 경우에 적용되는 것이다. 이 원칙은 편의성의 원 칙과 중복이 될 수 있다. 예를 들어, 운반차의 손잡이 폭 이 너무 넓어서 한국인 인체치수나 운전자의 인체치수를 고려하여 개선하도록 한 것이 이에 해당된다.

- 기타: 개선된 내용이 인간공학적 측면에서 필요한 것이 아니라, 장비의 내구성, 유지보수, 품질, 작업 생산성, 재배 환경과의 부합화 등을 고려하였을 때 개선이 필요한 경우 이다. 예를 들어, 운반차의 적재함 크기가 작목 수확용 박 스 크기와 맞지 않는 경우에 적재함 크기를 변경한 사례 가 이에 해당된다.

본 연구에서는 저자들이 인간공학적 전문성을 바탕으로 협의를 통해 각 개선 항목에 대한 적용 개선 원칙을 정하였 다. 개선 내용에 따라서는 상기 개선 원칙이 두 가지 이상 적용된 경우도 있다.

\section{Summary of Improvements}

\subsection{Powered cart with 4 wheels or caterpillar track}

4 륜 운반차(엔진, 전동, 궤도형 포함)의 개선 내용 및 원
리는 다음 Table 3 에 정리되어 있다. 개선 건수는 조종 장 치 관련이 33 건으로 가장 많았고, 다음으로 적재함, 핸들타 이어/바퀴 순으로 나타났다. 조종 장치 개선에서는 각종 조 종 장치의 기능을 쉽게 인지할 수 있도록 도와주는 범례를 부착하는 것이 가장 많았고, 안전성 향상을 위한 가속 장치 에 대한 개선이 다음으로 다수를 차지하였다. 적재함 부분은 농가의 작물 특성에 맞게 적재함 크기를 조정하거나 추가 적재가 가능하게 하는 보조 기구 부착에 관한 개선이 주를 이루고 있다. 구동부에서는 자동 운전 모드가 선택된 상태에 서 시동을 걸 때 급출발하는 문제를 개선한 사례가 가장 많 았다.

개선에 사용된 인간공학적 원칙은 안전성과 편의성이 37 건으로 같게 나타나, 운반차 개선에는 안전이나 사용상의 편이성이 중요한 관점임을 보여주고 있다.

Table 3. Improvements and their principles for 4-wheel driven carts

\begin{tabular}{|c|c|c|c|}
\hline Part & Improvements & Principle & $\mathrm{N}$ \\
\hline \multirow{13}{*}{$\begin{array}{l}\text { Controls } \\
\text { (조종 장치) }\end{array}$} & 기어시프트를 왼쪽에서 오른쪽으로 이동 & 편의성 & 2 \\
\hline & $\begin{array}{l}\text { 적재함 아래에 있어 조작이 어려운 초 } \\
\text { 크를 조작이 편한 위치로 이동 }\end{array}$ & 편의성 & 2 \\
\hline & 각종 조종 장치 기능을 알리는 범례 부착 & 편의성 & 12 \\
\hline & $\begin{array}{l}\text { 충전 단자에 덮개를 부착하여 이물질이 } \\
\text { 끼지 않게 함 }\end{array}$ & 안전성 & 2 \\
\hline & 시동/전후진 스위치 범례 개선 & 편의성 & 2 \\
\hline & $\begin{array}{l}\text { 토글 스위치로 되어 있는 구동 방식 선택 } \\
\text { 및 유압덤프 작동 스위치를 버튼식으로 } \\
\text { 변경 }\end{array}$ & 안전성 & 1 \\
\hline & $\begin{array}{l}\text { 위급 시 오조작을 예방하기 위하여 가속 } \\
\text { 스위치를 손잡이가 아닌 별도 공간에 부착 }\end{array}$ & 안전성 & 3 \\
\hline & 조작이 용이하도록 똑딱 스위치 방향 조정 & 편의성 & 1 \\
\hline & $\begin{array}{l}\text { 비상 정지 버튼과 차체의 색대비를 통한 } \\
\text { 시인성 제고 }\end{array}$ & 안전성 & 1 \\
\hline & 후진 시 경보 발생 & 안전성 & 2 \\
\hline & 운반차의 3 가지 정지 방법을 간소화함 & 안전성 & 1 \\
\hline & 전후진 스위치에 중립 위치를 추가 & 안전성 & 1 \\
\hline & $\begin{array}{l}\text { 가속 장치를 회전 방식(예: 오토바이)으로 } \\
\text { 변경 }\end{array}$ & 안전성 & 3 \\
\hline \multirow{8}{*}{$\begin{array}{l}\text { Cargo Box } \\
\text { (적재함) }\end{array}$} & 로프를 걸 수 있도록 고리 부착 & 기타 & 1 \\
\hline & 본체와의 연결 고리(클램프) 강화 & 안전성 & 2 \\
\hline & $\begin{array}{l}\text { 2단 적재 가능하게 가림판을 탈부착식 } \\
\text { 으로 하거나 높이를 높임 }\end{array}$ & 기타 & 8 \\
\hline & .3 면 개폐 가능하게 수정 & 기타 & 3 \\
\hline & 본체와 탈부착이 용이하도록 가이드 설치 & 기타 & 1 \\
\hline & 탈부착 손잡이 부착 & 편의성 & 1 \\
\hline & 탈부착식 2단 적재함 추가 & 편의성 & 1 \\
\hline & 적재함 골조 강화 & 기타 & 1 \\
\hline
\end{tabular}


Table 3. Improvements and their principles for 4-wheel driven carts (Continued)

\begin{tabular}{|c|c|c|c|}
\hline Part & Improvements & Principle & $\mathrm{N}$ \\
\hline \multirow{6}{*}{$\begin{array}{l}\text { Cargo Box } \\
\text { (적재함) }\end{array}$} & 재함 개폐 레버 개선 & 기타 & 1 \\
\hline & $\begin{array}{l}\text { 적재함 개폐 시 뒷/옆문이 수평 유지할 } \\
\text { 수 있게 함 }\end{array}$ & 편의성 & 2 \\
\hline & 작목 특성에 맞게 적재함 크기 변경 & 편의성 & 3 \\
\hline & 바닥에 미끄럼 방지 기능 추가 & 기타 & 1 \\
\hline & 분리형 보조 적재함 추가 & 기타 & 1 \\
\hline & $\begin{array}{l}\text { 비가림 덮개 부착 가능하도록 파이프 } \\
\text { 부착 }\end{array}$ & 기타 & 1 \\
\hline \multirow{12}{*}{$\begin{array}{c}\text { Engine/ } \\
\text { Power } \\
\text { transmission } \\
\text { (구동부 } \\
\text { (엔진, 풀리, } \\
\text { 벨트 등)) }\end{array}$} & $\begin{array}{l}\text { 운전자 반대 방향으로 부착되어 있는 시동 } \\
\text { 고리(리코일)를 운전자 쪽으로 향하게 함 }\end{array}$ & 편의성 & 1 \\
\hline & 클러치 조작 시의 소음 경감 & 기타 & 1 \\
\hline & 주행 최고 속도 상향 & 기타 & 1 \\
\hline & RPM을 낮추어 방향 전환이 용이하게 함 & 안전성 & 1 \\
\hline & $\begin{array}{l}\text { 시동 방식을 풀리 방식에서 스타트 모 } \\
\text { 터 방식으로 변경 }\end{array}$ & 편의성 & 2 \\
\hline & $\begin{array}{l}\text { 1줄로 되어 있는 동력 전달 벨트를 2줄 } \\
\text { 벨트로 변경 }\end{array}$ & 안전성 & 2 \\
\hline & $\begin{array}{l}\text { 풀리 홈을 } 2 \text { 개에서 } 4 \text { 개로 확대하여 타 } \\
\text { 장비 활용성을 높임 }\end{array}$ & 기타 & 1 \\
\hline & $\begin{array}{l}\text { 2륜/4륜 구동 선택을 } 4 \text { 륜 구동만 가능 } \\
\text { 하게 함 }\end{array}$ & 기타 & 1 \\
\hline & $\begin{array}{l}\text { 엔진 진동 경감을 위하여 차체 하부 방 } \\
\text { 진 고무 확대 }\end{array}$ & 기타 & 1 \\
\hline & 엔진 주변에 화상 위험 경고문 부착 & 안전성 & 2 \\
\hline & $\begin{array}{l}\text { 인력이 아닌 동력에 의한 회전 가능하 } \\
\text { 게 함 }\end{array}$ & 안전성 & 1 \\
\hline & $\begin{array}{l}\text { 자동 운전 모드에서 고속 출발로 인한 위 } \\
\text { 험을 경감하기 위하여 출발 속도를 줄임 }\end{array}$ & 안전성 & 5 \\
\hline \multirow{6}{*}{$\begin{array}{l}\text { Driving } \\
\text { handle } \\
\text { (핸들) }\end{array}$} & $\begin{array}{l}\text { 인체치수를 고려하여 높이를 2단으로 } \\
\text { 조절 가능하게 함 }\end{array}$ & 인체치수 & 4 \\
\hline & 여성 사용자를 고려하여 핸들 폭 축소 & 인체치수 & 1 \\
\hline & $\begin{array}{l}\text { 클러치 레버에 고무 부착(조작 시 손이 } \\
\text { 끼지 않도록) }\end{array}$ & 안전성 & 1 \\
\hline & $\begin{array}{l}\text { 조향 장치의 너클 부품을 주물로 제작 } \\
\text { 하여 견고하게 함 }\end{array}$ & 기타 & 1 \\
\hline & $\begin{array}{l}\text { 두 손으로 조작하는 핸들 방식 대신 한 } \\
\text { 손으로 조작 가능하게 레버식으로 변경 }\end{array}$ & 편의성 & 1 \\
\hline & $\begin{array}{l}\text { 핸들과 차체 사이 간격을 넓혀 회전 시 } \\
\text { 닿지 않도록 함 }\end{array}$ & 기타 & 1 \\
\hline \multirow{6}{*}{$\begin{array}{c}\text { Tire } \\
\text { /Caster } \\
\text { (타이어/ } \\
\text { 바퀴) }\end{array}$} & 본체와 연결 부위 강화 & 안전성 & 1 \\
\hline & 작목 환경에 맞게 타이어 간 폭 확대 & 기타 & 3 \\
\hline & 앞바퀴 2 개를 1 개로 변환 가능하게 함 & 안전성 & 1 \\
\hline & $\begin{array}{l}\text { 작목 특성에 맞추어 농용 바퀴를 산업 } \\
\text { 용 바퀴로 변경 }\end{array}$ & 기타 & 2 \\
\hline & 우레탄 재질 바퀴를 튜브식 바퀴로 변경 & 기타 & 1 \\
\hline & 서스펜션 기능 추가 & 안전성 & 2 \\
\hline
\end{tabular}

Table 3. Improvements and their principles for 4-wheel driven carts (Continued)

\begin{tabular}{|c|c|c|c|}
\hline Part & Improvements & Principle & $\mathrm{N}$ \\
\hline \multirow{3}{*}{$\begin{array}{c}\text { Tire } \\
\text { /Caster } \\
\text { (타이어/ } \\
\text { 바퀴) }\end{array}$} & 광폭 타이어 장착 & 안전성 & 1 \\
\hline & $\begin{array}{l}\text { 공기 주입구를 바깥쪽으로 향하게 하 } \\
\text { 여 사용이 편하게 함 }\end{array}$ & 편의성 & 1 \\
\hline & $\begin{array}{l}\text { 공기 주입구와 바퀴지지대 사이 간격 } \\
\text { 을 넓혀 내구성 강화 }\end{array}$ & 기타 & 1 \\
\hline \multirow{3}{*}{$\begin{array}{l}\text { Grip } \\
\text { (손잡이) }\end{array}$} & 핸들 손잡이 길이를 권장치에 맞게 늘림 & 인체치수 & 3 \\
\hline & 미끄러지지 않는 것으로 교체 & 안전성 & 1 \\
\hline & 가속 레버 멈춤 장치(핀) 부착 & 편의성 & 1 \\
\hline \multirow{3}{*}{$\begin{array}{l}\text { Cart Body } \\
\text { (차체) }\end{array}$} & 앞뒤 바퀴 간 폭 축소 & 안전성 & 1 \\
\hline & 차체 모서리 각진 부분을 없앰 & 안전성 & 1 \\
\hline & 차체 후면에 야광 스티커 부착 & 안전성 & 1 \\
\hline \multirow{4}{*}{$\begin{array}{c}\text { Brake } \\
\text { (브레이크) }\end{array}$} & $\begin{array}{l}\text { 한쪽에만 장착되어 있는 유압디스크 } \\
\text { 브레이크를 뒷바퀴 양쪽에 장착 }\end{array}$ & 기타 & 2 \\
\hline & 핸드 브레이크 추가 & 안전성 & 1 \\
\hline & $\begin{array}{l}\text { 핸드 브레이크에 넓은 커버를 씨워 조 } \\
\text { 작이 편하게 함 }\end{array}$ & 편의성 & 1 \\
\hline & $\begin{array}{l}\text { 핸드 브레이크 시인성을 높일 수 있도 } \\
\text { 록 범례 부착 }\end{array}$ & 기타 & 1 \\
\hline Gas tank & 연료양 게이지 부착 & 편의성 & 2 \\
\hline \multirow{2}{*}{$\begin{array}{l}\text { Control Box } \\
\text { (큰트롤박스) }\end{array}$} & $\begin{array}{l}\text { 운전자와 먼쪽으로 경사지게 하여 시 } \\
\text { 인성 제고 }\end{array}$ & 편의성 & 1 \\
\hline & 정속 주행 선택 기능 추가 & 편의성 & 1 \\
\hline
\end{tabular}

개선 사항 중 운반차 가속 조종 장치 형태가 레버, 클러치, 회전식(예: 오토바이 가속 방식) 등이 사용되고 있는데, 이 에 대해서는 사례에 따라 조금씩 다르게 개선하고 있어 안 전하며 사용 편의성이 높은 조종 장치 형태에 대한 연구가 필요하다. 적재함 부분에서도 적재 용량을 늘이기 위하여 적 재함 크기를 조정하거나, 2 단 적재가 가능하도록 보조 가림 막을 설치하거나 2단 적재함을 제작하기도 하고 있으나 이 의 작업 부하 및 안전성에 대한 체계적인 기준은 부족한 상 태이다. 자동 주행 모드로 셋팅된 상태에서 시동을 걸 경우 급출발하는 문제를 개선하기 위하여 저속으로 출발하도록 하였으나, 속도 기준이 명확하게 수립되어 있지 못하다. 조 작이 편하고 큰 힘을 낼 수 있는 운반차 핸들 폭에 대한 기 준도 없는 상태이다. 따라서 이러한 설계 기준에 대한 체계 적인 연구가 요망된다.

\subsection{Powered cart with 1 or 3 wheels}

운반차 1 륜과 3 륜은 모두 전동 운반차였으며, 개선 사례 를 정리한 표가 다음 Table 4 에 제시되어 있다. 개선 건수 가 26건으로 가장 많은 적재함을 살펴보면, 참외, 포도, 오 
이 등의 수확 작업 박스 크기에 맞도록 적재함 치수 개선이 가장 많았다. 또한, 적재함의 내리는 들기/내리기 작업 부하 경감 개선이 3 건, 수확, 보온 덮개, 모판 운반용과 같은 특수 용도 적재함 설계(Figure 1)가 3건이 있었다. 이 외에도 적 재함과 차체 결합을 볼트/너트 결합이 아닌 고리 방식으로 변경하여 편의성을 높인 개선이 있었다.

조종 장치 부분은 18 건의 개선이 있었으며, 적절한 표시 범례 부착 및 개선이 4 건으로 가장 많았다. 즉, 기존 운반차 에는 조종 장치에 대한 적절한 표시가 미비하다고 할 수 있 다. 1 륜 운반차의 경우 보조 바퀴의 탈부착이 가능하도록 하 는 개선이 3 건, 바퀴 폭을 작목 특성에 맞도록 개선한 것이 2건 있었다.

Table 4. Improvements and their principles for one or three-wheel driven carts

\begin{tabular}{|c|c|c|c|}
\hline Part & Improvements & Principle & $\mathrm{N}$ \\
\hline \multirow{15}{*}{$\begin{array}{l}\text { Cargo } \\
\text { box } \\
\text { (적재함) }\end{array}$} & $\begin{array}{l}\text { 수확 작업용 박스 크기에 맞도록 적재함 크 } \\
\text { 기 개선 }\end{array}$ & 기타 & 6 \\
\hline & $\begin{array}{l}\text { 중량물 취급 부하를 줄이도록 적재함 개선 } \\
\text { (적재함 측면을 개폐식으로 설계, 적재함 바 } \\
\text { 닥의 턱을 제거, 적재함 깊이를 줄임) }\end{array}$ & 안전성 & 3 \\
\hline & $\begin{array}{l}\text { 특수 용도 적재함 개발(수확용, 보온 덮개 운 } \\
\text { 반용, 모판 운반용, 직사각형 형태 및 위쪽이 } \\
\text { 더 넓은 형태 등) }\end{array}$ & 편의성 & 3 \\
\hline & $\begin{array}{l}\text { 적재함 크기 및 위치를 조정하여 좁은 공간 } \\
\text { (비닐 하우스 등) 작업이 가능하도록 개선 }\end{array}$ & 편의성 & 2 \\
\hline & $\begin{array}{l}\text { 적재함 모서리를 원형으로 개선하여 안전사 } \\
\text { 고 예방 }\end{array}$ & 안전성 & 2 \\
\hline & $\begin{array}{l}\text { 적재된 박스가 미끄러지지 않도록 미끄럼 방 } \\
\text { 지 패드 부착 }\end{array}$ & 기타 & 1 \\
\hline & 적재함의 무게를 줄임(파이프 등) & 편의성 & 1 \\
\hline & $\begin{array}{l}\text { 녹이 생기지 않는 재질로 변경(적재함, 볼트/ } \\
\text { 너트 등) }\end{array}$ & 기타 & 1 \\
\hline & $\begin{array}{l}\text { 적재함과 차체 고정 방식을 볼트/너트 식에서 } \\
\text { 고리 식으로 개선하여 적재함 탈부착을 용이 } \\
\text { 하게 함 }\end{array}$ & 편의성 & 1 \\
\hline & $\begin{array}{l}\text { 차체와 보강대 높이를 같게 하여 적재함 탈 } \\
\text { 부착을 용이하게 함 }\end{array}$ & 편의성 & 1 \\
\hline & $\begin{array}{l}\text { 적재함 테두리 및 가로봉을 일자 모양의 골이 } \\
\text { 없는 봉으로 교체하여 참외 적재 시 흠 방지 }\end{array}$ & 기타 & 1 \\
\hline & $\begin{array}{l}\text { 적재함을 부착하지 않은 상태에서도 수확용 상 } \\
\text { 자 및 바구니를 적재할 수 있도록 구조 개선 }\end{array}$ & 기타 & 1 \\
\hline & $\begin{array}{l}\text { 적재함과 바퀴 공간을 넓게 하여 이물질이 } \\
\text { 끼지 않도록 개선 }\end{array}$ & 기타 & 1 \\
\hline & $\begin{array}{l}\text { 수확용 상자가 적재함에 잘 밀착하도록 보조 } \\
\text { 파이프 설치 }\end{array}$ & 기타 & 1 \\
\hline & $\begin{array}{l}\text { 적재함 주위 남는 공간을 보조 적재 공간으 } \\
\text { 로 활용하도록 개선 }\end{array}$ & 기타 & 1 \\
\hline \multirow{2}{*}{$\begin{array}{l}\text { Controls } \\
\text { (조종 장치) }\end{array}$} & $\begin{array}{l}\text { 적절한 표시 범례 부착(전/후진, 자동/수동 스 } \\
\text { 위치 등) }\end{array}$ & 편의성 & 4 \\
\hline & $\begin{array}{l}\text { 전/후진 조작과 운전(스피드) 조작이 모두 오 } \\
\text { 른손에 집중되어 있는 것을 왼손으로도 가능 } \\
\text { 하도록 개선 }\end{array}$ & 편의성 & 3 \\
\hline
\end{tabular}

Table 4. Improvements and their principles for one or three-wheel driven carts (Continued)

\begin{tabular}{|c|c|c|c|}
\hline Part & Improvements & Principle & $\mathrm{N}$ \\
\hline \multirow{9}{*}{$\begin{array}{l}\text { Controls } \\
\text { (조종 장치) }\end{array}$} & 출발 시 저속에서 서서히 가속되도록 개선 & 안전성 & 2 \\
\hline & 후진 전용 스위치 추가 부착(비닐 하우스 작업) & 편의성 & 2 \\
\hline & 전원 표시 범례 개선(켜짐-초록색, 꺼짐-빨간색) & 양립성 & 1 \\
\hline & $\begin{array}{l}\text { 조종 박스(전/후진 스위치)가 손잡이와 너무 가 } \\
\text { 까워 손과 접촉이 되는 경우 손잡이와 멀리 위 } \\
\text { 치시킴 }\end{array}$ & 안전성 & 1 \\
\hline & $\begin{array}{l}\text { 전/후진 조작 스위치 박스를 가깝게 위치시키 } \\
\text { 도록 } 180 \text { 도 회전시킴 }\end{array}$ & 편의성 & 1 \\
\hline & $\begin{array}{l}\text { 날카로운 조종 박스를 부드러운 곡선 형태로 } \\
\text { 개선 }\end{array}$ & 안전성 & 1 \\
\hline & $\begin{array}{l}\text { 속도 선택 토글 스위치를 개념적 양립성에 맞 } \\
\text { 도록 개선(전방: 고속, 후방: 저속) }\end{array}$ & 양립성 & 1 \\
\hline & $\begin{array}{l}\text { 조작부의 지지대를 없애고 전진/후진, 속도 조 } \\
\text { 절기만 설치해 간단히 조작 가능토록 구조 개선 }\end{array}$ & 편의성 & 1 \\
\hline & $\begin{array}{l}\text { 버튼식(전진, 후진)의 조작 장치를 레버식 속 } \\
\text { 도조절기로 변경하여 비상 시 정지 기능 }\end{array}$ & 안전성 & 1 \\
\hline \multirow{10}{*}{$\begin{array}{l}\text { Tire } \\
\text { /Caster } \\
\text { (바퀴) }\end{array}$} & $\begin{array}{l}\text { 보조 바퀴를 탈부착 가능하도록 하여 조작을 } \\
\text { 용이하게 함 }\end{array}$ & 안전성 & 3 \\
\hline & 바퀴 폭 개선(참외: 광폭, 포도: $18 \mathrm{~cm}$-> 12cm) & \begin{tabular}{|c|} 
안전성, \\
기타
\end{tabular} & 2 \\
\hline & $\begin{array}{l}\text { 발포 우레탄 바퀴로 교체(튜브가 없어 유지성 } \\
\text { 좋음, 진동 방지) }\end{array}$ & 기타 & 1 \\
\hline & 바퀴 위치 이동(작업자와 접촉 방지) & 안전성 & 1 \\
\hline & $\begin{array}{l}\text { 바퀴가 방향 전환 시 배터리 케이스와 접촉이 } \\
\text { 되지 않도록 위치, 간격 개선 }\end{array}$ & 기타 & 1 \\
\hline & $\begin{array}{l}\text { 차체와 바퀴 간격을 넓게 하여 }(2 \sim 3 \mathrm{~cm}->5 \sim 6 \\
\mathrm{cm}) \text { 무거운 적재물 운반 시 차체와 접촉 방지 }\end{array}$ & 기타 & 1 \\
\hline & $\begin{array}{l}\text { 주 바퀴 간격을 고랑 폭에 맞게 축소 }(38 \mathrm{~cm}) \text { 하 } \\
\text { 여 전도 가능성 줄임 }\end{array}$ & 안전성 & 1 \\
\hline & 플라스틱 보조 바퀴를 고무 타이어(광폭)로 교체 & 기타 & 1 \\
\hline & 보조 바퀴 간격 개선 (포도, $35 ~ 40 \mathrm{~cm}$ ) & 기타 & 1 \\
\hline & $\begin{array}{l}\text { 바퀴와 바퀴 고정 파이프 간격을 넓혀 흙 등 } \\
\text { 의 밀착 방지 }\end{array}$ & 기타 & 1 \\
\hline \multirow{5}{*}{$\begin{array}{c}\text { Balance } \\
\text { (무게 중심) }\end{array}$} & $\begin{array}{l}\text { 배터리를 앞쪽으로 이동하여 무게중심을 앞쪽 } \\
\text { 으로 이동 }\end{array}$ & 안전성 & 1 \\
\hline & $\begin{array}{l}\text { 바퀴 위치를 작업자와 먼 쪽으로 이동하여 무 } \\
\text { 게중심을 작업자 쪽으로 이동 }\end{array}$ & 안전성 & 1 \\
\hline & $\begin{array}{l}\text { 상자를 적재함 후면에 실었을 때 무게 중심을 } \\
\text { 맞추기 위해 차체 아래 부분에 중심 추를 추 } \\
\text { 가 장착 }\end{array}$ & 안전성 & 1 \\
\hline & $\begin{array}{l}\text { 타이어 고정 부위에 구멍을 } 2 \text { 개 뚫어 필요에 } \\
\text { 따라 무게 중심을 이동할 수 있게 함 }\end{array}$ & 안전성 & 1 \\
\hline & $\begin{array}{l}\text { 앞쪽의 무게 추를 제거하고, 적재함을 최대한 } \\
\text { 작업자 쪽으로 이동 }\end{array}$ & 안전성 & 1 \\
\hline \multirow{3}{*}{$\begin{array}{c}\text { Grip } \\
\text { (손잡이) }\end{array}$} & $\begin{array}{l}\text { 손잡이 높이를 조작이 용이하도록 변경(case 1: } \\
57 \mathrm{~cm} \rightarrow>53 \mathrm{~cm} \text {, case 2: } 60 \mathrm{~cm} \rightarrow>50 \mathrm{~cm} \text { ) }\end{array}$ & 인체치수 & 2 \\
\hline & $\begin{array}{l}\text { 손잡이 너비를 잡기 용이하도록 변경(case 1: } 57 \\
\mathrm{~cm} \rightarrow>60 \mathrm{~cm} \text {, case 2: } 50 \mathrm{~cm} \rightarrow 558 \mathrm{~cm})\end{array}$ & 인체치수 & 2 \\
\hline & $\begin{array}{l}\text { 고무 손잡이를 견고하게 고정(돌출부 설치 혹은 } \\
\text { 고정) }\end{array}$ & 기타 & 1 \\
\hline
\end{tabular}


Table 4. Improvements and their principles for one or three-wheel driven carts (Continued)

\begin{tabular}{|c|c|c|c|}
\hline Part & Improvements & Principle & $\mathrm{N}$ \\
\hline \multirow{4}{*}{$\begin{array}{l}\text { Cart Body } \\
\text { (차체) }\end{array}$} & $\begin{array}{l}\text { 좁은 공간(하우스 등)에서의 방향 전환 등 } \\
\text { 이 용이하도록 차체 길이를 줄임 }\end{array}$ & 편의성 & 2 \\
\hline & $\begin{array}{l}\text { 폭이 좁은 고랑에서 작물과의 접촉을 방지 } \\
\text { 하기 위해 차체의 폭을 변경 }\end{array}$ & 편의성 & 1 \\
\hline & $\begin{array}{l}\text { 차체 구조 보강(차체-손잡이 연결 부위, 차 } \\
\text { 체 용접 강화) }\end{array}$ & 기타 & 2 \\
\hline & $\begin{array}{l}\text { 차체 각진 부위에 PVC 마개를 쓰워 접촉 } \\
\text { 위험을 줄임 }\end{array}$ & 안전성 & 1 \\
\hline \multirow{2}{*}{$\begin{array}{c}\text { Support } \\
\text { (지지대) }\end{array}$} & 지지대 아래 부분 구조 강화 & 기타 & 4 \\
\hline & $\begin{array}{l}\text { 지지대 너비 변경 } \\
\text { (비닐하우스: } 31 \mathrm{~cm} \text {, 과수원: } 55 \mathrm{~cm} \text { ) }\end{array}$ & 기타 & 2 \\
\hline \multirow{5}{*}{$\begin{array}{l}\text { Battery } \\
\text { (배터리) }\end{array}$} & 배터리 잔량 표시 장치 설치 & 편의성 & 1 \\
\hline & $\begin{array}{l}\text { 배터리 케이스 앞 커버를 나사 방식에서 } \\
\text { 슬라이딩 방식으로 개선 }\end{array}$ & 편의성 & 1 \\
\hline & $\begin{array}{l}\text { 배터리 케이스 모서리 부분을 날카롭지 않 } \\
\text { 도록 개선 }\end{array}$ & 안전성 & 1 \\
\hline & $\begin{array}{l}\text { 충전과 휴즈의 위치 재배열로 인지성과 사 } \\
\text { 용성 향상 }\end{array}$ & 편의성 & 1 \\
\hline & 배터리 조작 스위치 범례 부착 & 편의성 & 1 \\
\hline $\begin{array}{c}\text { Power } \\
\text { Transmission } \\
\text { (구동부) }\end{array}$ & $\begin{array}{l}\text { 흙과 물 등의 유입 방지(모터의 위치를 높 } \\
\text { 이고, 체인 커버 가림판 설치) }\end{array}$ & 기타 & 2 \\
\hline \multirow{6}{*}{$\begin{array}{c}\text { Miscellaneous } \\
\text { parts } \\
\text { (기타) }\end{array}$} & 후진 시 후진 경고음 발생 및 개선 & 안전성 & 2 \\
\hline & $\begin{array}{l}\text { 운반차 식별을 위해, 배터리 윗부분에 일련 } \\
\text { 번호 부착 }\end{array}$ & 기타 & 1 \\
\hline & $\begin{array}{l}\text { 야간 작업을 위한 라이트 부착 및 탈부착 } \\
\text { 이 용이하도록 개선 }\end{array}$ & 기타 & 2 \\
\hline & $\begin{array}{l}\text { 전선이 외부로 드러나지 않도록 정리 및 } \\
\text { 고정 }\end{array}$ & 안전성 & 1 \\
\hline & $\begin{array}{l}\text { 조종 박스 위치를 작업자 무릎과 닿지 않 } \\
\text { 도록 뒤로 이동 및 플라스틱 재질로 변경 }\end{array}$ & 안전성 & 1 \\
\hline & $\begin{array}{l}\text { 조종 박스 커버를 쓰워 물이 들어가지 않 } \\
\text { 게 개선 }\end{array}$ & 기타 & 2 \\
\hline
\end{tabular}

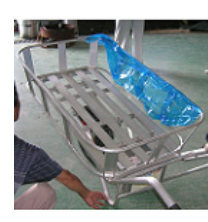

(a) 수확용

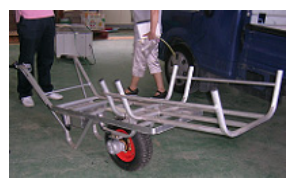

(b) 보온덮개용

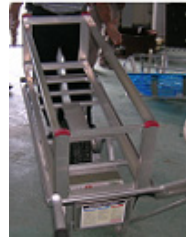

(c) 모판 운반용
Figure 1. Cargo boxes for special purposes

1 륜 운반차의 경우, 전진/후진은 전기 모터로 작동하지만, 이동 시 차체 지탱 및 회전은 인력으로 이루어지므로 4 륜 전동차와 달리 무게 중심이 중요하여 이를 개선한 사례가 5 건 있었다. 그러나 각 개선 사례별로 농업인 및 전문가의
주관적 경험과 지식에 의존하여 개선이 이루어졌으며, 적절 한 무게 중심에 대한 가이드라인 연구가 필요하다. 손잡이의 경우 높이, 너비 개선이 4 건이 있었으며, 1 륜 전동차에서 요구되는 힘인 들기와 회전 힘 발휘에 적합한 손잡이 높이 및 너비 연구가 필요하다고 판단된다.

\subsection{Other equipments}

\subsubsection{Grass cutter}

보행용 제초기 2 종, 승용 제초기 1 종에 대한 개선 사항을 정리한 표가 다음 Table 5에 제시되어 있다. 제초기의 경우 칼날 부위 차폐가 중요하고, 제초 작업 시 돌이나 기타 물질 이 작업자 방향으로 튀는 것을 방지하는 보호 장치 개선이 있었다. 또한, 보행 제초기의 경우 높이 조절 방식이 수작업 으로 막대를 돌려 고정 너트를 꽉 조이는 방식인데, 기존 제 초기는 큰 힘이 요구되고 접촉 스트레스가 있는 것을 손잡이 가 달린 형태로 교체하고, 막대 길이를 늘려 주도록 개선하 였다(Figure 2). 그러나, 막대 길이와 작업 자세에 따른 근 력 측정 등을 통한 적절한 지침 개발이 요구된다.



(a) Before improvement

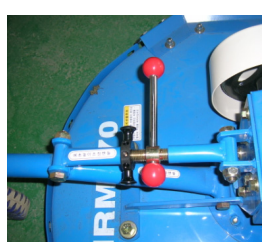

(b) After improvement
Figure 2. Improvements of devices for adjusting height for grass-cutter

Table 5. Improvements and their principles for grass-cutter

\begin{tabular}{|c|c|c|c|}
\hline Part & Improvements & Principle & $\mathrm{N}$ \\
\hline \multirow{2}{*}{$\begin{array}{l}\text { Height } \\
\text { adjustment } \\
\text { (높이 조절 } \\
\text { 장치) }\end{array}$} & $\begin{array}{l}\text { 높이 조절 막대가 짧고 손잡이가 없는 것 } \\
\text { 을, 볼 손잡이가 달린 긴 쇠막대로 교체 }\end{array}$ & 편의성 & 1 \\
\hline & $\begin{array}{l}\text { 높이 고정용 6각 너트를 소형 손잡이가 } \\
\text { 달린 너트로 교체하여 작은 힘으로 작 } \\
\text { 업할 수 있도록 개선 }\end{array}$ & 편의성 & 1 \\
\hline \multirow{2}{*}{$\begin{array}{l}\text { Cart Body } \\
\text { (차체) }\end{array}$} & $\begin{array}{l}\text { 제초기의 작업자 쪽 고무 가림막을 } 2 \text { 중 } \\
\text { 으로 설치하여 땅 바닥과 가림막 공간 } \\
\text { 을 최소화하여 돌 등의 튐 방지 }\end{array}$ & 안전성 & 1 \\
\hline & $\begin{array}{l}\text { 기타(차체 가림막 부위 철판을 두꺼운 } \\
\text { 철판으로 교체, 차체와 가림막 철판 연 } \\
\text { 결 용접을 강화) }\end{array}$ & 안전성 & 2 \\
\hline \multirow{2}{*}{$\begin{array}{c}\text { Cutter } \\
\text { (칼날 부분) }\end{array}$} & $\begin{array}{l}\text { 칼날 주위 고무패드를 길고 튼튼하게 개 } \\
\text { 선하고, 경고 스티커 부착하여 사고 예방 }\end{array}$ & 안전성 & 2 \\
\hline & $\begin{array}{l}\text { 좌우 칼날 부위가 땅 바닥의 높이에 따라 } \\
\text { 자동으로 높낮이가 조절하게 하여, 땅 바 } \\
\text { 닥 상태에 관계없이 예초가 가능하게 함 }\end{array}$ & 기타 & 1 \\
\hline
\end{tabular}


Table 5. Improvements and their principles for grass-cutter (Continued)

\begin{tabular}{c|l|c|c}
\hline Part & \multicolumn{1}{|c|}{ Improvements } & Principle & $\mathrm{N}$ \\
\hline \multirow{3}{*}{$\begin{array}{c}\text { Display } \\
\text { (표시 범례) }\end{array}$} & $\begin{array}{l}\text { 조종 장치 표시 범례를 잘 보이는 곳에 } \\
\text { 박(예초 높이 조정 핸들, 저속, 고속 핸 }\end{array}$ & 편의성 & 2 \\
\cline { 2 - 4 } & 레버) & & \\
\cline { 2 - 4 } & 영문 범례를 한글 범례로 교체 & 편의성 & 1 \\
\hline
\end{tabular}

\subsubsection{Conveyors}

차량이나 창고에서 하물 상하차에 사용되는 컨베이어벨트, 흘렉시블 컨베이어(일명 자바라)에 대한 개선 사례가 Table 6 에 정리되어 있다. 컨베이어 벨트의 미끄럼 방지, 추락 방 지를 위한 형태 변경, 농가 실정에 맞게 폭을 조정하는 등 하물 상하차 시 안전성을 향상시키기 위한 개선이 가장 많 았다(5건). 활용된 개선 원칙으로는 안전성이 7 건으로 가장 많아, 하물 상하차에는 하물이 손상되지 않도록 하는 안전이 가장 우선적으로 고려됨을 보이고 있다.

컨베이어에 하물 상하차 시 개선 사례로 보고된 하물을

Table 6. Improvements and their principles for conveyor

\begin{tabular}{|c|c|c|c|}
\hline Part & Improvements & Principle & $\mathrm{N}$ \\
\hline \multirow{3}{*}{$\begin{array}{l}\text { Controls } \\
\text { (조종 장치) }\end{array}$} & $\begin{array}{l}\text { 상차 부위에만 있던 컨베이어 높낮이 } \\
\text { 조절 장치를 컨베이어 상하차 양쪽 끝 } \\
\text { 에 설치 }\end{array}$ & 편의성 & 1 \\
\hline & $\begin{array}{l}\text { 방향 전환 장치가 없어 큰 인력을 요 } \\
\text { 구하나 앞바퀴에 방향 전환 장치를 추 } \\
\text { 가하여 방향 전환이 용이하게 함 }\end{array}$ & 편의성 & 1 \\
\hline & $\begin{array}{l}\text { 하차 부위에만 있던 비상 정지 버튼을 } \\
\text { 상하차 양쪽에 설치 }\end{array}$ & 안전성 & 1 \\
\hline \multirow{5}{*}{$\begin{array}{l}\text { Supporting } \\
\text { Frame } \\
\text { (지지대) }\end{array}$} & $\begin{array}{l}\text { 일직선 형태이던 컨베이어를 하차 부분 } \\
\text { 끝 부분 약 } 60 \mathrm{~cm} \text { 정도를 평평하게 하 } \\
\text { 여 하물을 수평 상태에서 하차할 수 } \\
\text { 있게 함 }\end{array}$ & 안전성 & 1 \\
\hline & $\begin{array}{l}\text { 벨트 표면이 일자 혹은 물결 무늬로만 } \\
\text { 되어 있어 하물이 미끄러질 수 있으나, } \\
\text { 바닥 무늬를 V자 형태로 하여 미끄러 } \\
\text { 짐을 방지함 }\end{array}$ & 안전성 & 1 \\
\hline & $\begin{array}{l}\text { 농가 창고 출입문 크기에 맞게 벨트 } \\
\text { 폭을 조정함 }\end{array}$ & 기타 & 1 \\
\hline & $\begin{array}{l}\text { 높이 조절이 용이하도록 높이를 눈금 } \\
\text { 표시로 나타냄 }\end{array}$ & 편의성 & 1 \\
\hline & $\begin{array}{l}\text { 운반 분하를 줄일 수 있도록 분해와 } \\
\text { 조립이 용이하도록 함 }\end{array}$ & 안전성 & 1 \\
\hline \multirow{2}{*}{$\begin{array}{l}\text { Tire } \\
\text { (타이어) }\end{array}$} & $\begin{array}{l}\text { 앞바퀴에만 있는 바퀴 고정 장치를 앞 } \\
\text { 뒤 바퀴 모두에 설치 }\end{array}$ & 안전성 & 1 \\
\hline & $\begin{array}{l}\text { 우레탄 재질의 바퀴를 농촌 환경에 맞 } \\
\text { 게 튜브식으로 교체 }\end{array}$ & 안전성 & 1 \\
\hline $\begin{array}{l}\text { Sub frame } \\
\text { (보조기기) }\end{array}$ & $\begin{array}{l}\text { 상하차 작업 시 밀거나 끌어내릴 수 } \\
\text { 있는 보조기기를 부착 }\end{array}$ & 안전성 & 1 \\
\hline
\end{tabular}

밀어 내리거나 끌어 올리는 보조 도구의 명확한 설계 기준 (예: 컨베이어 높이에 따른 경사각, 들기 작업과의 부하 및 작업 효율 비교 등)이 제시되어 있지 않아, 이에 대한 실험 적 연구가 요망된다.

\subsubsection{Pest control machines}

Table 7은 방제 작업 관련 편이장비의 개선 사례를 정리 한 것이다. 방제기 개선 사례 중 안전성과 관련된 대표적인 사례는 구동용 벨트가 외부에 노출되어 있는 것을 덮개로 차단한 것을 들 수 있으며(Figure 3), 엔진 및 배기부의 고온부를 차단하도록 한 것도 안전성 개선에 해당된다. 방제 기 개선 사례 중 편의성과 관련된 것은 리모콘의 정지 버튼 단순화, 버튼의 기능별로 다른 색상으로 표시, 조작 레버의 방향과 위치 조정을 통해 손목의 자세 개선 등이 있다. 방 제기 조작용 운전 레버의 폭은 한국인 인체치수를 고려하여 $50 \sim 75 \mathrm{~mm}$ 로 하도록 개선한 것은 인체치수를 적용한 사례 에 해당된다.

Table 7. Improvements of pest control machines

\begin{tabular}{|c|c|c|c|}
\hline Part & Improvements & Principle & $\mathrm{N}$ \\
\hline \multirow{5}{*}{$\begin{array}{l}\text { Control } \\
\text { (조종 장치) }\end{array}$} & $\begin{array}{l}\text { 정지, 감김, 풀림의 기능별로 색을 달 } \\
\text { 리하도록 할 것 }\end{array}$ & 편의성 & 1 \\
\hline & 기능별로 표시 범례 부착 & 편의성 & 3 \\
\hline & $\begin{array}{l}\text { 조종 박스를 운전자에게 잘 보이고 접 } \\
\text { 근하기 좋도록 함 }\end{array}$ & 편의성 & 1 \\
\hline & $\begin{array}{l}\text { 동일 기능 복수 버튼 제거 위해 정지 } \\
\text { 버튼을 하나로 단순화 }\end{array}$ & 편의성 & 1 \\
\hline & $\begin{array}{l}\text { 정지 버튼은 빨간색으로, 감김/풀림 버 } \\
\text { 튼은 색이 구별되게 함 }\end{array}$ & 양립성 & 1 \\
\hline \multirow{3}{*}{$\begin{array}{l}\text { Engine/Power } \\
\text { Transmission } \\
\text { (엔진/구동부) }\end{array}$} & $\begin{array}{l}\text { 외부에 노출된 엔진의 소음에 대한 차 } \\
\text { 음 장치 필요함 }\end{array}$ & 안전성 & 1 \\
\hline & $\begin{array}{l}\text { 고온부에 철망 설치하여 사람의 접촉 } \\
\text { 차단; 화상 주의 스티커 부착; 호스 등 } \\
\text { 주변 부분이 고온부에 접촉되지 않도 } \\
\text { 록 배치 }\end{array}$ & 안전성 & 2 \\
\hline & $\begin{array}{l}\text { 구동용 벨트, 기어 부분 안전 덮개로 } \\
\text { 차단(협착 사고 예방) }\end{array}$ & 안전성 & 2 \\
\hline \multirow{4}{*}{$\begin{array}{l}\text { Driving } \\
\text { handle } \\
\text { (핸들) }\end{array}$} & $\begin{array}{l}\text { 손잡이 봉을 높이고, 본체와의 거리를 } \\
\text { 넓혀서 운전 시 손목의 불편한 자세 } \\
\text { 개선 }\end{array}$ & 안전성 & 1 \\
\hline & 레버 폭을 줄임(권장치 $50 \sim 75 \mathrm{~mm}$ ) & 인체치수 & 1 \\
\hline & $\begin{array}{l}\text { 레버의 방향 및 각도를 조정해 손가락/ } \\
\text { 손목의 불편한 자세 개선 }\end{array}$ & 안전성 & 2 \\
\hline & $\begin{array}{l}\text { 브레이크 고정 장치 설치(경사길에서 } \\
\text { 강제 고정 가능) }\end{array}$ & 안전성 & 1 \\
\hline $\begin{array}{l}\text { Hose Reel } \\
\text { (호스릴) }\end{array}$ & $\begin{array}{l}\text { 호스가 다 감기면 감기 기능이 즉시 } \\
\text { 멈추도록 함 }\end{array}$ & 기타 & 3 \\
\hline
\end{tabular}


Table 7. Improvements of pest control machines (Continued)

\begin{tabular}{|c|c|c|c|}
\hline Part & Improvements & Principle & $\mathrm{N}$ \\
\hline $\begin{array}{l}\text { Gas tank } \\
\text { (연료통) }\end{array}$ & 연료량이 잘 보이도록 표시 범례 부착 & 편의성 & 1 \\
\hline $\begin{array}{c}\text { Caster } \\
\text { (보조바퀴) }\end{array}$ & $\begin{array}{l}\text { 받침대 길이를 약 } 10 \mathrm{~mm} \text { 더 길게 하여 } \\
\text { 발로 조작 쉽게 함 }\end{array}$ & 편의성 & 1 \\
\hline $\begin{array}{c}\text { Brake } \\
\text { (브레이크) }\end{array}$ & $\begin{array}{l}\text { 브레이크 케이블 연결 부분에 캡을 쓰 } \\
\text { 워 물로 인한 고장 예방 }\end{array}$ & 기타 & 1 \\
\hline $\begin{array}{l}\text { Belt } \\
\text { (벨트) }\end{array}$ & $\begin{array}{l}\text { 등짐용 벨트에 완충 쿠션을 달아 어깨 } \\
\text { 부담 최소화 }\end{array}$ & 편의성 & 1 \\
\hline
\end{tabular}

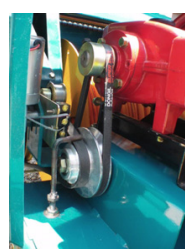

(a) Before improvement



(b) After improvement
Figure 3. Improvement for blocking driving wheel parts of pest control machine

\subsubsection{Miscellaneous equipments}

Table 8은 작목에 따라 사용이 제한적이거나 사례가 적었 던 편이장비들의 개선 사례로서, 쪽파용 자동결속기, 배꼭지 작업용 작업대, 파종기, 수동 비닐피복기, 비닐하우스 자동 비닐개폐기가 포함되었다.

자동결속기는 동력 전달 체인부에 접근을 차단하는 방호 막 설치, 작업 속도 조절 장치 설치 등과 같이 결속 작업을 수행 농업인의 안전성을 높이기 위한 개선과 결속기에 쪽파 를 투입하기 위해서 준비 작업을 하는데 필요한 보조 작업대 를 장착하여 작업의 편의성을 높이는 개선이 대표적으로 이 루어졌다.

배꼭지 작업대는 작업대 높이를 조절식을 하며, 작업대 상 판의 크기를 우리나라 여자 성인의 팔길이를 기준으로 설계 하도록 하는 편의성 향상과 인체치수 적용 원칙이 주요 개 선 사항이었다.

파종기는 채소류 씨앗을 자동으로 심는 장비로서 조종 장 치에 대한 표시 범례의 부착, 고온 주의 표시문과 부속 변경 설명문의 시인성 향상 등과 같이 표시 장치 개선을 통한 편 의성 향상 개선이 주로 이루어졌다.

수동 피복기는 상대적으로 단순한 제품으로서 날카로운 모서리를 둥글게 하는 개선과 조립 연결 부위를 표시하여 쉽게 조립할 수 있도록 하는 개선이 있다.

비닐개폐기는 조종 패널과 컨트롤박스에 있는 사용자인터
페이스를 개선하여 사용 농업인들이 조종기의 기능을 쉽게 파악할 수 있도록 하고, 개폐기 운용 상태를 제대로 파악할 수 있도록 피드백을 주도록 하는 개선이 이루어졌다.

Table 8. Improvements of various equipments: automatic tying machine, pear work table, automatic seeder, vinyl covering machine, automatic door of green house

\begin{tabular}{|c|c|c|c|c|}
\hline Equipment & Part & Improvements & Principle & $\mathrm{N}$ \\
\hline \multirow{7}{*}{$\begin{array}{l}\text { Binding } \\
\text { machine } \\
\text { (chives) } \\
\text { (쪽파결속기) }\end{array}$} & \multirow{3}{*}{ 구동부 } & 협착 사고 주의 경고문 부착 & 안전성 & 1 \\
\hline & & 작업 속도를 조절식으로 설계 & 안전성 & 1 \\
\hline & & $\begin{array}{l}\text { 동력전달 체인부에 접근 차 } \\
\text { 단용 방호막 설치 }\end{array}$ & 안전성 & 1 \\
\hline & 에어건 & 흙/이물질 제거용 에어건 부착 & 기타 & 1 \\
\hline & $\begin{array}{l}\text { 조종 } \\
\text { 장치 }\end{array}$ & $\begin{array}{l}\text { 주요 조종 장치에 기능 표시 } \\
\text { 범례 부착 }\end{array}$ & 편의성 & 1 \\
\hline & 콤프레서 & $\begin{array}{l}\text { 본체, 콤프레서 일체형 제작 } \\
\text { (이동/운반을 쉽게 함) }\end{array}$ & 기타 & 1 \\
\hline & 투입구 & $\begin{array}{l}\text { 쪽파 투입부에 보조 작업대 } \\
\text { 설치(준비 작업 공간) }\end{array}$ & 편의성 & 1 \\
\hline \multirow{3}{*}{$\begin{array}{l}\text { Workstation } \\
\text { (Pear) } \\
\text { (배 작업대) }\end{array}$} & \multirow{3}{*}{$\begin{array}{l}\text { 작업대 } \\
\text { 상판 }\end{array}$} & $\begin{array}{l}\text { 작업대 높이 조절식 제작(높이 } \\
\text { 조절 용이하게 할) }\end{array}$ & 인체치수 & 1 \\
\hline & & $\begin{array}{l}\text { 작업대 아래에 망 설치(작업 } \\
\text { 대 틈으로 배 포장 재료가 떨 } \\
\text { 어지지 않게 함) }\end{array}$ & 기타 & 1 \\
\hline & & $\begin{array}{l}\text { 작업대 상판의 반지름을 여자 } \\
\text { 성인의 평균 팔길이 }(65.7 \mathrm{~cm}) \text { 보 } \\
\text { 다 } 10 \mathrm{~cm} \text { 크게 함 }\end{array}$ & 인체치수 & 1 \\
\hline \multirow{5}{*}{$\begin{array}{l}\text { Sowing } \\
\text { machine } \\
\text { (파종기) }\end{array}$} & $\begin{array}{l}\text { 깊이 } \\
\text { 조절기 }\end{array}$ & 깊이 조절 눈금 표시 부착 & 편의성 & 1 \\
\hline & \multirow{2}{*}{$\begin{array}{l}\text { 조종 } \\
\text { 장치 }\end{array}$} & $\begin{array}{l}\text { 깊이조절기, 기어 등에 대한 } \\
\text { 기능 표시 범례 부착 }\end{array}$ & 편의성 & 1 \\
\hline & & 손잡이 커버 설치 & 안전성 & 1 \\
\hline & 엔진 & $\begin{array}{l}\text { 고온 주의 표시문의 시인성 } \\
\text { 제고(크기, 색) }\end{array}$ & 안전성 & 1 \\
\hline & $\begin{array}{l}\text { 부속 } \\
\text { 변경 } \\
\text { 안내문 } \\
\end{array}$ & $\begin{array}{l}\text { 파종 종자별 부속 교체 설명 } \\
\text { 문의 시인성 개선(그림 사용, } \\
\text { 글자 크기 확대, 색 활용) }\end{array}$ & 편의성 & 1 \\
\hline \multirow{2}{*}{$\begin{array}{l}\text { Vinyl covering } \\
\text { cachine } \\
\text { (비닐피복기) }\end{array}$} & 조립부 & $\begin{array}{l}\text { 조립을 위한 순서 및 위치 표 } \\
\text { 시 범례 부착 }\end{array}$ & 편의성 & 1 \\
\hline & 모서리 & $\begin{array}{l}\text { 모서리의 날카로운 부분 제거, } \\
\text { 안전덮개 장착 }\end{array}$ & 안전성 & 1 \\
\hline \multirow{4}{*}{$\begin{array}{l}\text { Automatic } \\
\text { door } \\
\text { (비닐개폐기) }\end{array}$} & \multirow[b]{2}{*}{$\begin{array}{l}\text { 조종 } \\
\text { 패널 }\end{array}$} & $\begin{array}{l}\text { 자동/수동 전환 버튼을 설치 } \\
\text { (농업인 선택 사용 가능) }\end{array}$ & 편의성 & 1 \\
\hline & & $\begin{array}{l}\text { 조종 패널 전면 상단부에 LED } \\
\text { 패널 부착(시스템 조작 내용 } \\
\text { 및 운용 상태 표시) }\end{array}$ & 편의성 & 1 \\
\hline & \multirow{2}{*}{$\begin{array}{l}\text { 조종 } \\
\text { 박스 }\end{array}$} & $\begin{array}{l}\text { 조종 박스 측면에 시건 장치 } \\
\text { 부착(무단조작 방지) }\end{array}$ & 기타 & 1 \\
\hline & & $\begin{array}{l}\text { 시스템 작동상태 표시 적색등 } \\
\text { (조종 박스 전면 부착) }\end{array}$ & 편의성 & 1 \\
\hline
\end{tabular}




\section{Ergonomic Principles of Improvements}

앞서 장비별로 살펴본 개선 사례에서 적용된 인간공학적 원칙을 장비별로 빈도 분석을 한 결과가 다음 Table 9 에 제시되어 있다. 전체적으로 가장 많이 적용된 원칙은 안전성 (91건, 33\%)이었으며, 편의성 (89건, 31\%), 기타 (85건, $30 \%$ ) 순이었다(그림 4참조). 적용된 장비별로도 인간공학 적 개선 원칙의 빈도가 전체적인 수준과 비슷하게 나타났다. 장비별로는 운반차가 218 건으로 전체 개선 건수의 약 $76 \%$ 를 차지하여 가장 많았다.

개선 건수가 많은 개선 부위별 개선 원칙의 빈도분석 결 과는 다음 Table 10에 제시되어 있다. 조종 장치에 대한 개 선이 70건으로 가장 많았으며, 다음으로 엔진/구동부, 타이 어/바퀴, 손잡이/핸들 순으로 나타났다. 손잡이/핸들의 경우 인체치수 원칙이 $54 \%$ 로 가장 많았으며, 조종 장치 부분의 개선에서는 편의성 원칙이 $64 \%$ 로 가장 많이 적용되었다.

Table 9. Frequency analysis of the applied ergonomic principles by equipment(number, percentage)

\begin{tabular}{|c|c|c|c|c|c|c|}
\hline Equipments & Safety & $\begin{array}{l}\text { Ease } \\
\text { of use }\end{array}$ & Anthropometry & Compatibility & Etc. & Total \\
\hline $\begin{array}{c}\text { Carts } \\
\text { (4 wheels, } \\
\text { caterpillar } \\
\text { track) }\end{array}$ & $\begin{array}{c}38 \\
(32.2)\end{array}$ & $\begin{array}{c}37 \\
(31.4)\end{array}$ & $\begin{array}{c}8 \\
(6.8)\end{array}$ & $\begin{array}{c}0 \\
(0.0)\end{array}$ & $\begin{array}{c}35 \\
(29.6)\end{array}$ & $\begin{array}{c}118 \\
(100.0)\end{array}$ \\
\hline $\begin{array}{c}\text { Carts } \\
\text { (1 wheel, } \\
4 \text { wheels) }\end{array}$ & $\begin{array}{c}26 \\
(22.0)\end{array}$ & $\begin{array}{c}26 \\
(22.0)\end{array}$ & $\begin{array}{c}4 \\
(3.4)\end{array}$ & $\begin{array}{c}2 \\
(1.7)\end{array}$ & $\begin{array}{c}40 \\
(33.9)\end{array}$ & $\begin{array}{c}98 \\
(100.0)\end{array}$ \\
\hline $\begin{array}{l}\text { Grass cutter } \\
\text { Conveyor } \\
\text { Pest Control } \\
\text { Machine }\end{array}$ & $\begin{array}{c}21 \\
(45.6)\end{array}$ & $\begin{array}{c}17 \\
(37.0)\end{array}$ & $\begin{array}{c}1 \\
(2.2)\end{array}$ & $\begin{array}{c}1 \\
(2.2)\end{array}$ & $\begin{array}{c}6 \\
(13.0)\end{array}$ & $\begin{array}{c}46 \\
(100)\end{array}$ \\
\hline $\begin{array}{l}\text { Miscellaneous } \\
\text { machines }\end{array}$ & $\begin{array}{c}6 \\
(28.6)\end{array}$ & $\begin{array}{c}9 \\
(42.9)\end{array}$ & $\begin{array}{c}2 \\
(9.5)\end{array}$ & $\begin{array}{c}0 \\
(0)\end{array}$ & $\begin{array}{c}4 \\
(19.0)\end{array}$ & $\begin{array}{c}21 \\
(100.0)\end{array}$ \\
\hline Total & $\begin{array}{c}91 \\
(32.2)\end{array}$ & $\begin{array}{c}89 \\
(31.4)\end{array}$ & $\begin{array}{c}15 \\
(5.3)\end{array}$ & $\begin{array}{c}3 \\
(1.1)\end{array}$ & $\begin{array}{c}85 \\
(30.0)\end{array}$ & $\begin{array}{c}283 \\
(100.0)\end{array}$ \\
\hline
\end{tabular}

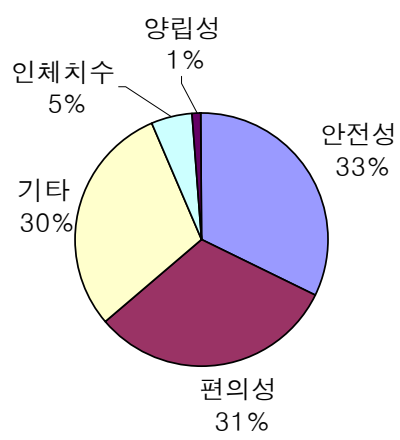

Figure 4. Frequencies of the applied ergonomic principles
적재함, 타이어/바퀴, 엔진 구동부, 적재함에서는 안전성이 가장 많이 개선 원리로 활용되었다.

Table 10. Frequency analysis of the applied ergonomic principles by equipment part(number, percentage)

\begin{tabular}{c|c|c|c|c|c|c}
\hline Equipments & Safety & $\begin{array}{c}\text { Ease } \\
\text { of use }\end{array}$ & Anthropometry & Compatibility & Etc. & Total \\
\hline $\begin{array}{c}\text { Driving } \\
\text { handle }\end{array}$ & $\begin{array}{c}6 \\
(25.0)\end{array}$ & $\begin{array}{c}2 \\
(8.3)\end{array}$ & $\begin{array}{c}13 \\
(54.2)\end{array}$ & $\begin{array}{c}0 \\
(0.0)\end{array}$ & $\begin{array}{c}3 \\
(12.5)\end{array}$ & $\begin{array}{c}24 \\
(100.0)\end{array}$ \\
\hline Controls & $\begin{array}{c}21 \\
(30.0)\end{array}$ & $\begin{array}{c}45 \\
(64.3)\end{array}$ & $\begin{array}{c}0 \\
(0)\end{array}$ & $\begin{array}{c}3 \\
(4.3)\end{array}$ & $\begin{array}{c}1 \\
(1.4)\end{array}$ & $\begin{array}{c}70 \\
(100.0)\end{array}$ \\
\hline Tire/Caster & 12 & 2 & 0 & 0 & 15 & 29 \\
$(41.4)$ & $(6.9)$ & $(0)$ & $(0)$ & $(51.7)$ & $(100.0)$ \\
\hline $\begin{array}{c}\text { Engine/Power } \\
\text { Transmission }\end{array}$ & $\begin{array}{c}19 \\
(59.4)\end{array}$ & $\begin{array}{c}6 \\
(18.8)\end{array}$ & $\begin{array}{c}0 \\
(0)\end{array}$ & $\begin{array}{c}0 \\
(0)\end{array}$ & $\begin{array}{c}7 \\
(21.8)\end{array}$ & $\begin{array}{c}32 \\
(100.0)\end{array}$ \\
\hline Cargo box & $\begin{array}{c}8 \\
(14.8)\end{array}$ & $\begin{array}{c}15 \\
(27.8)\end{array}$ & $\begin{array}{c}0 \\
(0)\end{array}$ & $\begin{array}{c}0 \\
(0)\end{array}$ & $\begin{array}{c}31 \\
(57.4)\end{array}$ & $\begin{array}{c}54 \\
(100.0)\end{array}$ \\
\hline $\begin{array}{c}\text { Miscellaneous } \\
\text { parts }\end{array}$ & $\begin{array}{c}25 \\
(33.8)\end{array}$ & $\begin{array}{c}19 \\
(25.7)\end{array}$ & $\begin{array}{c}2 \\
(2.7)\end{array}$ & $\begin{array}{c}0 \\
(0)\end{array}$ & $\begin{array}{c}28 \\
(37.8)\end{array}$ & $\begin{array}{c}74 \\
(100.0)\end{array}$ \\
\hline
\end{tabular}

\section{Conclusion}

본 연구에서는 14 개 시군 33 개 작목반에서 저자들이 수 행한 50건의 편이장비에 대한 283건의 개선 사례를 장비별 및 개선 부분별로 정리 - 제시하였다. 개선 장비별로는 운반 차가 전체 약 $76 \%$ 를 차지하여 가장 많아, 중량물 취급 작업 의 부하를 경감시킬 수 있는 장비 보급에 초점을 맞춘 편이 장비 보급 사업의 취지에 적절하게 장비가 선정된 것으로 보인다. 장비의 개선 부분은 조종 장치와 적재함의 개선 빈 도가 높게 나타났다. 개선 사례와 더불어 개선에 적용된 인 간공학적 원칙을 제시하였으며, 안전성과 편의성 원칙이 전 체 사례 중 각각 $33 \%, 31 \%$ 로 가장 활용된 것으로 나타났 다. 따라서 추후 농작업 편이장비 개발 시에 이러한 관점에 대한 우선적 검토가 있어야 할 것으로 판단된다.

본 연구의 결과는 추후 이루어질 편이장비 보급 사업에서 의 개선 및 새로운 장비 개발 시 지침으로 사용될 수 있을 것으로 기대된다. 본 연구에서는 편이장비 개선에 보편적 인 간공학적 원칙만을 적용하였으나, 편이장비에 특화된 분야 (예: 1 륜 운반차의 무게 중심 위치, 운반차의 핸들 폭 등)에 대한 실험적 연구가 이루어진다면 좀 더 체계적인 개선 및 설계 지침 마련이 가능할 것으로 판단된다. 


\section{References}

Park, K. H. and Jeong, B. Y., Study about the characteristics of old worker' musculoskeletal systems, Proceedings of the Ergonomics Society of Korea Conference, 215-218, 2008.

Kee, D., Survey of musculoskeletal disorders of farmers, Journal of the KOSOS, 24(3), 59-64, 2009.

Park, D., Ergonomic risk factors of musculoskeletal disorders in agricultural work, Rural Life and Science, 21(2), 59-67, 2000.

\section{Author listings}

Doyung Kee: dhkee@kmu.ac.kr

Highest degree: Ph.D., Department of Industrial Engineering, POSTECH Position title: Professor, Department of Industrial and Management Engineering, Keimyung University Areas of interest: Population stereotype, Product design, Posture classification scheme
Yong W. Song: songyw@cu.ac.kr

Highest degree: Ph.D., Department of Industrial Engineering, POSTECH Position title: Professor, Department of Occupational Health, Catholic University of Daegu

Areas of interest: Biomechanics, Electromyography

\section{Inseok Lee: lis@hknu.ac.kr}

Highest degree: Ph.D., Department of Industrial Engineering, POSTECH Position title: Professor, Department of Safety Engineering, Hankyong National University

Areas of interest: Ergonomics in Safety and Health, Agricultural Ergonomics, Accessible Design

Date Received : 2011-07-02

Date Revised :2011-07-18

Date Accepted : 2011-07-19 